\title{
Ato InFRACIONAL ADOLESCENTE: \\ QUEM NÃO PODE FALAR ADOECE
}

Caroline Weiss Albuquerque

O presente estudo surge das observações feitas em um espaço de escuta oferecido dentro do judiciário a jovens que cometeram ato infracional. Numa vida em meio à violência e à pobreza, como pensar em subjetividade nesse território? Como jovens marginalizados em sua condição e vistos como marginais podem existir numa cultura que os desloca? Levando em consideração que o jovem que delinque pede ajuda, entendemos como importante que ele se responsabilize pelo seu ato, o que implica mudança subjetiva, possível apenas através do discurso.

\section{BANCA:}

Junia de Vilhena (Orientadora)

Anna Paula Uziel

Beatriz de Souza Lima

Data de defesa: 05/03/2010 